\title{
Single- and Multispecies Biofilms by Escherichia coli, Staphylococcus aureus, and Salmonella spp. Isolated from Raw Fish and a Fish Processing Unit
}

\author{
Jesieli Braz Frozi ${ }^{1}$ Luciana Maria Ramires Esper ${ }^{2}$ Robson Maia Franco ${ }^{3}$
}

${ }^{1}$ Programa de Pós-graduação em Higiene Veterinária e Processamento Tecnológico de Produtos de Origem Animal, Universidade Federal Fluminense (UFF), Rua Dr. Mário Viana, 523, Bairro Santa Rosa, 24241-002, Niterói, RJ, Brasil. Email: jesielibraz@yahoo.com.br. Corresponding author. ${ }^{2}$ Faculdade de Farmácia, Departamento de Bromatologia, Universidade Federal Fluminense (UFF), Niterói, RJ, Brasil. ${ }^{3}$ Faculdade de Veterinária, Departamento de Tecnologia de Alimentos, Universidade Federal Fluminense (UFF), Niterói, RJ, Brasil.

ABSTRACT: The consumption of fish by the Brazilian population is increasing. However, fish and seafood are highly perishable and can be contaminated with several microorganisms. In addition, the possibility of biofilm formation is a greater cause for concern. In this study, biofilm formation was evaluated in single-and multispecies cultures at $25^{\circ} \mathrm{C}$ for incubation periods of 0, 4, 8, 24, and 48h in stainless steel coupons (size, $1.0 \times 1.0 \mathrm{~cm}$ ) immersed in tryptic soy broth. The characteristics of the formed biofilms after sanitizing by immersing the coupons in 200 ppm sodium hypochlorite solution for 10min were also evaluated under the same experimental conditions but with some modifications. Biofilm structure was evaluated using scanning electron microscopy. Analysis of single-species biofilms indicated that all bacterial strains formed biofilms at different intervals without any statistically significant difference. However, comparison of the growth of single- and multispecies cultures indicated a significantly higher biofilm formation by the pure cultures. In multispecies biofilms, compared with the other microorganisms, growth of Salmonella spp. was significantly lower for all tested incubation periods; whereas, of Staphylococcus aureus was significantly higher than that of E. coli until $8 \mathrm{~h}$ of incubation; the differences in growth were not significantly different after this incubation period. Sanitizing with sodium hypochlorite was effective because no cell growth was observed in the coupons that were treated with 200ppm sodium hypochlorite for 10min. This study demonstrated the ability of isolated microorganisms to form biofilms, reinforcing the need for food handling establishments to adopt good manufacturing practices, developing adequate protocols for cleaning and disinfecting surfaces and equipment used in food production, maintaining and replacing equipment when necessary.

Key words: Salmonella spp., Escherichia coli, Staphylococcus aureus, biofilm, stainless steel, fish industry.

Formação de Biofilmes Mono e Multi-espécies de Escherichia coli, Staphylococcus aureus, e Salmonella spp. Isoladas de Pescado Cru e Indústria de Pescado

RESUMO: A população brasileira tem apresentado um elevado consumo de peixes, no entanto pescados são alimentos altamente perecíveis e podem ser contaminados por uma diversidade de microrganismos. A situação ainda é mais alarmante quando se trata da formação de biofilmes. Para verificação da formação de biofilme, as cepas foram testadas dentro de cultivos mono e multi-espécies a $25^{\circ} \mathrm{C}$ durante o tempo total de 48h, onde as análises foram realizadas no tempo 0 e nos intervalos de 4, 8, 24 e 48h em cupom de aço inoxidável medindo 1,0x1,0cm, imersos em caldo TSB (Tryptic Soy Broth).O comportamento dos biofilmes formados, diante da sanitização por imersão dos cupons em solução de hipoclorito de sódio a 200ppm por 10 minutos, também foi avaliado, nas mesmas condições citadas acima, com algumas particularidades. A avaliação estrutural foi procedida por microscopia de varredura eletrônica (MEV). Nos resultados de biofilmes mono-espécie, foi verificado que todas as cepas foram capazes de formar biofilme, nos diferentes tempos, sem diferenças estatisticamente significativas. Entretanto, comparandose o crescimento de culturas mono e múltiplas espécies observou-se formação de biofilme, estatisticamente maior, entre as culturas puras. Nas culturas multi-espécies, Salmonella spp. apresentou crescimento, estatisticamente menor, em todos os tempos, entre os microrganismos testados, enquanto $S$. aureus apresentou maior crescimento que E. coli até 8 horas de incubação, deste tempo em diante a diferença não foi significativa. Quanto ao comportamento frente sanitização com hipoclorito, o sanitizante foi eficaz, uma vez que não foi observado crescimento celular nas análises dos cupons tratados com a solução de hipoclorito a 200ppm por 10 minutos. Este estudo demonstrou a capacidade dos microrganismos isolados em formar biofilmes, reforçando, a importância dos estabelecimentos manipuladores de alimentos investirem em treinamento de Boas Práticas de Fabricação, desenvolvimento de protocolos adequados de limpeza e desinfecção de áreas e equipamentos envolvidos na produção de alimentos e manutenção e troca desses sempre que se fizer necessário.

Palavras-chave: Salmonella spp., Escherichia coli, Staphylococcus aureus, biofilme, aço inoxidável, indústria pesqueira.

\section{INTRODUCTION}

The consumption of fish in Brazil is increasing, as revealed in the BULLETIN OF THE MINISTÉRIO DA PESCA E AQUICULTURA
(2011), indicating an average increase of $23.7 \%$ in the consumption of fish and seafood in 2010 and 2011. The ministry attributed the increased consumption to better living conditions of the Brazilian population and the demand for healthier foods. 
Although healthy, fish products are a major source of contamination because they are susceptible to contamination in the marine environment and can harbor pathogenic microorganisms (IWAMOTO et al., 2010). The situation is even more concerning with the possibility of the formation of densely populated sessile bacterial communities, which is known as biofilms. These are communities formed by single or several bacterial species and allow the microorganisms to survive in hostile environments. Biofilms comprise a matrix formed by an extracellular polymeric substance (EPS), which is responsible for the cohesion and adhesion of bacterial cells to surfaces, and channels for the circulation of nutrients. Biofilm formation in equipment and food processing surfaces causes several problems, including the corrosion of metal surfaces and cross-contamination of food products (MENON, 2016). It is important to note that sanitizers do not easily penetrate the matrix of the biofilms formed after an inefficient cleaning process (SIMÕES et al., 2005).

Fish products are more susceptible to decay compared with other animal products. This susceptibility can be explained by intrinsic factors such as high phospholipid and enzyme levels, marked water activity, nearly neutral $\mathrm{pH}$, and nutrient diversity that can be used by microorganisms (GHALY et al., 2010).

This study aimed to assess the capacity of single- and multispecies biofilm formation by strains of Escherichia coli, Staphylococcus aureus, and Salmonella spp. isolated from raw fish and a fish processing unit on stainless steel surfaces, evaluating the characteristics of the biofilms after sanitizing.

\section{MATERIALS AND METHODS}

The experiments were conducted using strains of E. coli, S. aureus, and Salmonella spp. obtained from raw fish and a fish processing unit (Table 1), which were kindly provided by the Laboratory of Food Hygiene of theUniversidade Federal Fluminense. The microorganisms were identified using biochemical tests and Gram staining.

The capacity of single- and multispecies biofilm formation and their resistance to hypochlorite sanitizer was evaluated using AISI 304 stainless steel coupons with a no. 4-brushed surface finish. The structural characteristics of the biofilms and the formation of exopolysaccharides were analyzed using scanning electron microscopy (SEM). The stainless steel material is widely used by the food industry in manufacturing equipment, countertops, and utensils. The stainless steel coupons used measure $1.0 \times 1.0 \mathrm{~cm}$. The coupons were sterilized and immersed in tubes that contained $10 \mathrm{~mL}$ trypticase soy broth (TSB), and the initial count of the cell suspension of each microorganism was $10^{5} \mathrm{CFU} / \mathrm{mL}^{-1}$, which was confirmed by plating. The coupons were subsequently incubated at $25^{\circ} \mathrm{C}$, and biofilm formation was evaluated at 4h (T4), 8h (T8), 24h (T24), and 48h (T48).The coupons submerged in the non inoculated sterile culture medium were used as controls. Trials were performed in triplicate.

The stainless steel coupons were removed from the TSB culture medium using sterile forceps and were submerged in $10 \mathrm{~mL}$ phosphate-buffered salt (PBS) for $1 \mathrm{~min}$ to remove planktonic cells. The coupons were subsequently transferred to test tubes that contained $5 \mathrm{~mL}$ PBS and were vortexed for $2 \mathrm{~min}$ to remove sessile cells. The number of cells adhered to each coupon $\left(\mathrm{CFU} \mathrm{\textrm {cm } ^ { - 2 } )}\right.$ was determined by transferring serial dilutions to Petri dishes (surface plating) that contained trypticase soy agar (TSA) and incubating the Petri dishes at $35^{\circ} \mathrm{C} \pm 1^{\circ} \mathrm{C}$ for 48h (ESPER, 2010).

The procedure used to evaluate the capacity of multispecies biofilm formation was the

Table 1 - Strains of Escherichia coli, Staphylococcus aureus, and Salmonella spp. isolated from raw fish and a fish processing unit.

\begin{tabular}{lcc}
\hline Microorganism & Code & Origin \\
\hline S. aureus & A12 & Salmon sushi \\
S. aureus & EED11 & Conveyor surface in a fish processing unit \\
Salmonella. spp. & EED2 & Conveyor surface in a fish processing unit \\
Salmonella. spp. & EEA22 & Conveyor surface in a fish processing unit \\
E. coli & TRD22V & Reception tank in a fish processing unit \\
E. coli & TRD21V & Reception tank in a fish processing unit \\
E. coli coli & EED23V & Conveyor surface in a fish processing unit \\
\hline E. coli & EED22V & Conveyor surface in a fish processing unit \\
\hline coli & ECSL & Salmon \\
\hline
\end{tabular}


same used that used for single-species tests, except that in the preparation of TSB tubes for incubation at $25^{\circ} \mathrm{C}$ at different incubation periods, one strain of each microorganism, with an initial count of $10^{5} \mathrm{UFC} /$ $\mathrm{mL}$, was inoculated in each test tube. The criterion for selecting each strain was the highest growth in the singlespecies test (strains EED11, EEA22, and ECSL). After each incubation period, selective plating was performed using Baird-Parker agar, methylene blue-eosin agar, and Hektoen agar for the identification and count of $S$. aureus, E. coli, and Salmonella spp., respectively. The hypochlorite sanitizer resistance test followed the same protocol as the previous tests, with the difference that after $1 \mathrm{~min}$ immersion in $10 \mathrm{~mL}$ PBS, the coupons were immersed in 200ppm sodium hypochlorite solution for $10 \mathrm{~min}$, transferred to test tubes containing $5 \mathrm{~mL}$ PBS, and vortexed. Plating was performed on TSA, and the plates were read after incubation. For the evaluation of biofilm structure using SEM, the samples were prepared and dried at the critical point of $\mathrm{CO}_{2}$, and the coupons were mounted in stubs and metallized in a gold plating bath (SILVEIRA, 1998).

Three independent experiments were performed in duplicate. Results were evaluated by analysis of variance and Tukey's test at a level of significance of $5 \%(\mathrm{P}<0.05)$ using the GraphPad Prism ${ }^{R}$ software version 5.01 .

\section{RESULTS AND DISCUSSION}

The evaluated $S$. aureus strains showed biofilm formation capacity on AISI 304 stainless steel surfaces and a gradual increase in biofilm formation up to T24, with a significant difference between the two strains A12 and EED11 up to 24h of incubation. However, the surface-isolated strain EED11 had improved biofilm formation compared with the food-isolated strain A12. This result may be because of the better adaptation of the former to the surface environment because this strain (EED11) was isolated from stainless steel obtained from a fish processing unit. After T24, biofilm formation by strain A12 was less pronounced, and there was a small decrease in biofilm formation by strain EED11. No significant difference in biofilm formation was observed at T48.

The two strains of Salmonella spp. isolated from the fish processing unit also showed biofilm formation capacity; this capacity was similar up to T48 at $25^{\circ} \mathrm{C}$, and no significant difference was reported.

Under the same conditions, biofilms were formed by the $E$. coli strains, which showed a continuous growth during the 48-h incubation period. Biofilm formation by the E. coli strain isolated from salmon was significantly higher than that by the other studied strains after $24 \mathrm{~h}$ of incubation. However, there were no significant differences in biofilm formation among the $E$. coli strains in the $48 \mathrm{~h}$ incubation period.

In contrast to $S$. aureus strains, the $E$. coli strain with the best biofilm formation capacity was isolated from food. This result indicated that even food-isolated strains that are not previously adapted to the surface environment can quickly form biofilms and highlights the importance of hygiene practices because this food-isolated strain can be an important source of contamination.

The comparison of single-species cultures revealed an alternation of the isolates with the highest capacity of biofilm formation at different incubation periods. At T4, biofilm formation was highest by Salmonella spp., followed by $E$. coli at T8 and $S$. aureus at T24. At T48, biofilm formation was similar among the bacterial strains but without significant difference. Figure 1 shows the characteristics of the biofilms of E. coli, S. aureus, and Salmonella spp. on the tested surfaces.

In the multispecies tests, a smaller number of colonies of E. coli, S. aureus, and Salmonella spp. adhered to the stainless steel surface compared with the single-species tests under the same conditions (Figure 2).

The difference in biofilm formation between single- and multispecies cultures was statistically significant. Among the evaluated strains, Salmonella spp. formed less biofilms at all incubation periods, possibly because of its limited ability to compete. ALMEIDA et al. (2011) observed the formation of two-species biofilms at different incubation periods (2, 4, 6, 24, and 48h) using ATCC strains of Salmonella enteritis and $E$. coli on coupons made with seven different materials, including stainless steel, and incubated at $21^{\circ} \mathrm{C}$ in TSB; they observed that E. coli produced more biofilms than S.enteritis on all the coupons, thereby corroborating the current study results. The authors also emphasized the ability of $E$. coli to produce large quantities of exopolymers, which were easily observed by the naked eye, and the lower capacity of biofilm formation by Salmonella spp. was attributed to its limited ability to compete for nutrients.

The characteristics of $S$. aureus strains in this study, which produced significantly more biofilms than $E$. coli until T8, and no significant difference in biofilm formation after T8 disagrees with the study results of POMPERMAYER \& GAYLARDE (2000), where in multispecies biofilm formation was observed in strains of $E$. coli and $S$. aureus isolated from chicken carcasses at different time periods $(2,4,6$, and $8 \mathrm{~h})$ and different temperatures $\left(12^{\circ} \mathrm{C}\right.$ and $30^{\circ} \mathrm{C}$ ) on polyethylene surfaces. There was a 


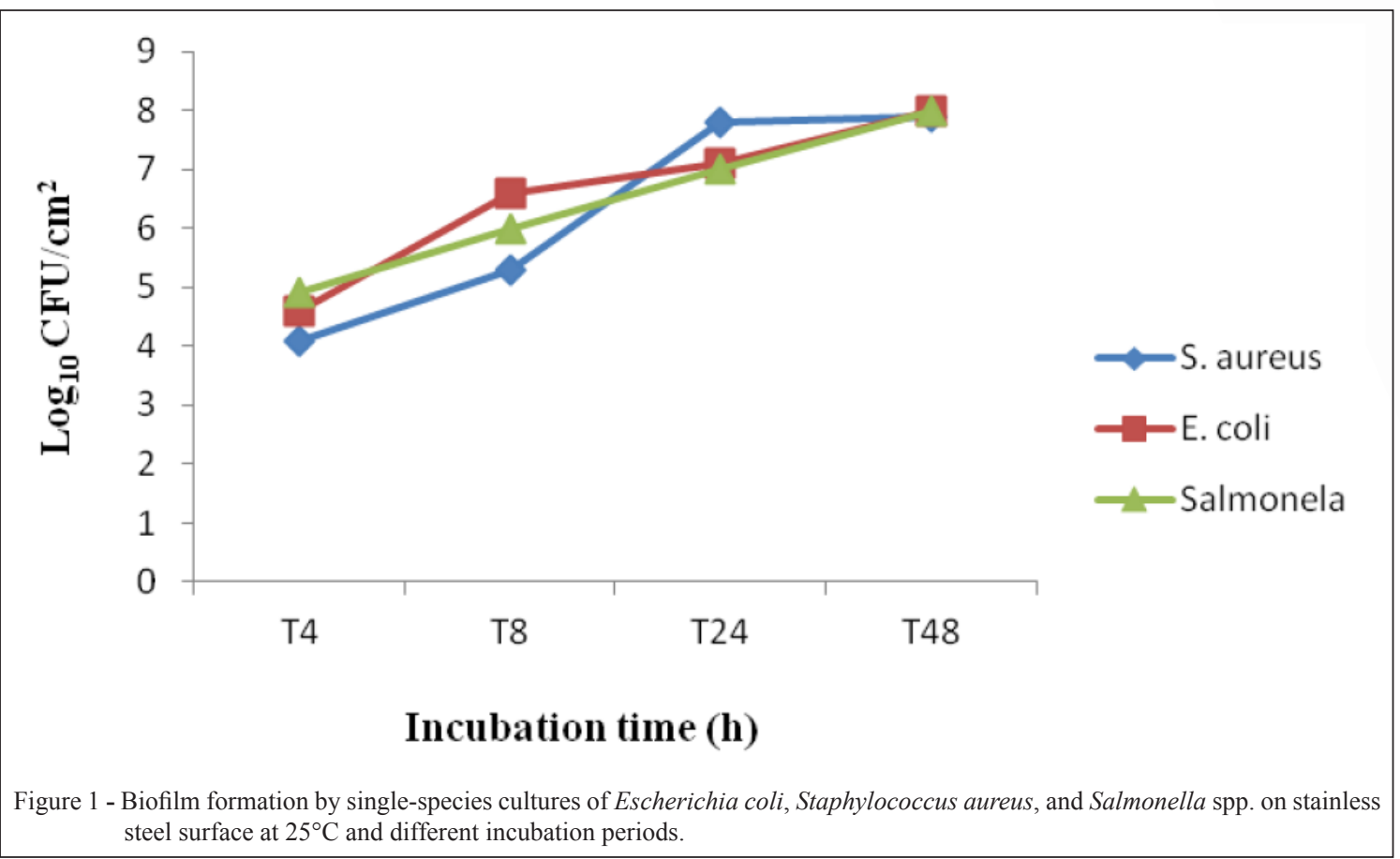

significantly higher adhesion of E. coli compared with $S$. aureus at both temperatures. This result was expected because of the shorter generation time of $E$. coli and suggested that $S$. aureus, known to be a weak competitor, can overcome this limitation by having a higher growth than E. coli.
Biofilms comprising E. coli, S. aureus, and Salmonella spp. were analyzed using SEM to enable better visualization of the cells after 24 and $48 \mathrm{~h}$ of incubation at $25^{\circ} \mathrm{C}$ (Figure 3). Figure 3 showed the single- and multispecies biofilms formed after $24 \mathrm{~h}$ of incubation at $25^{\circ} \mathrm{C}$.

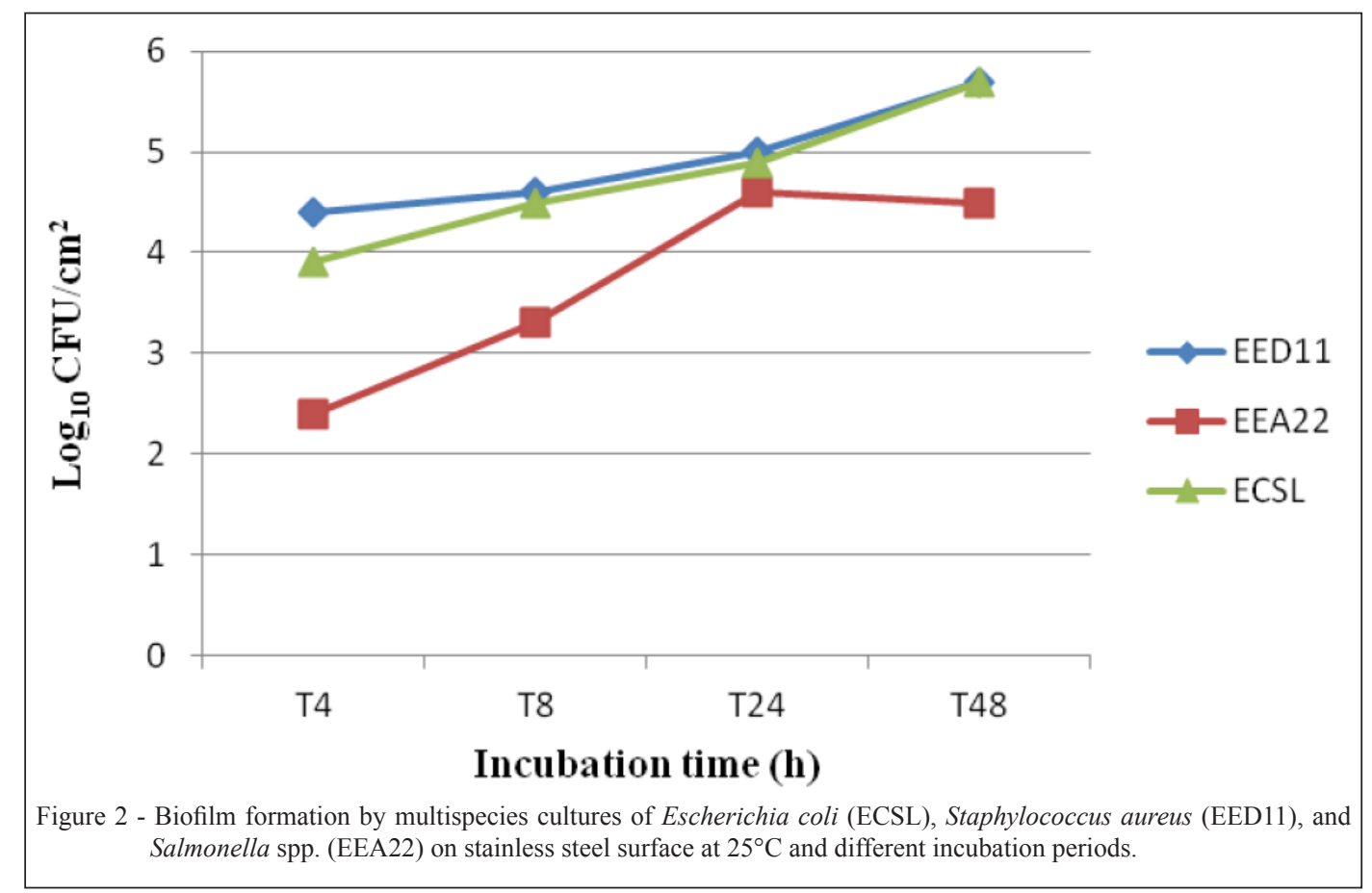

Ciência Rural, v.47, n.10, 2017. 

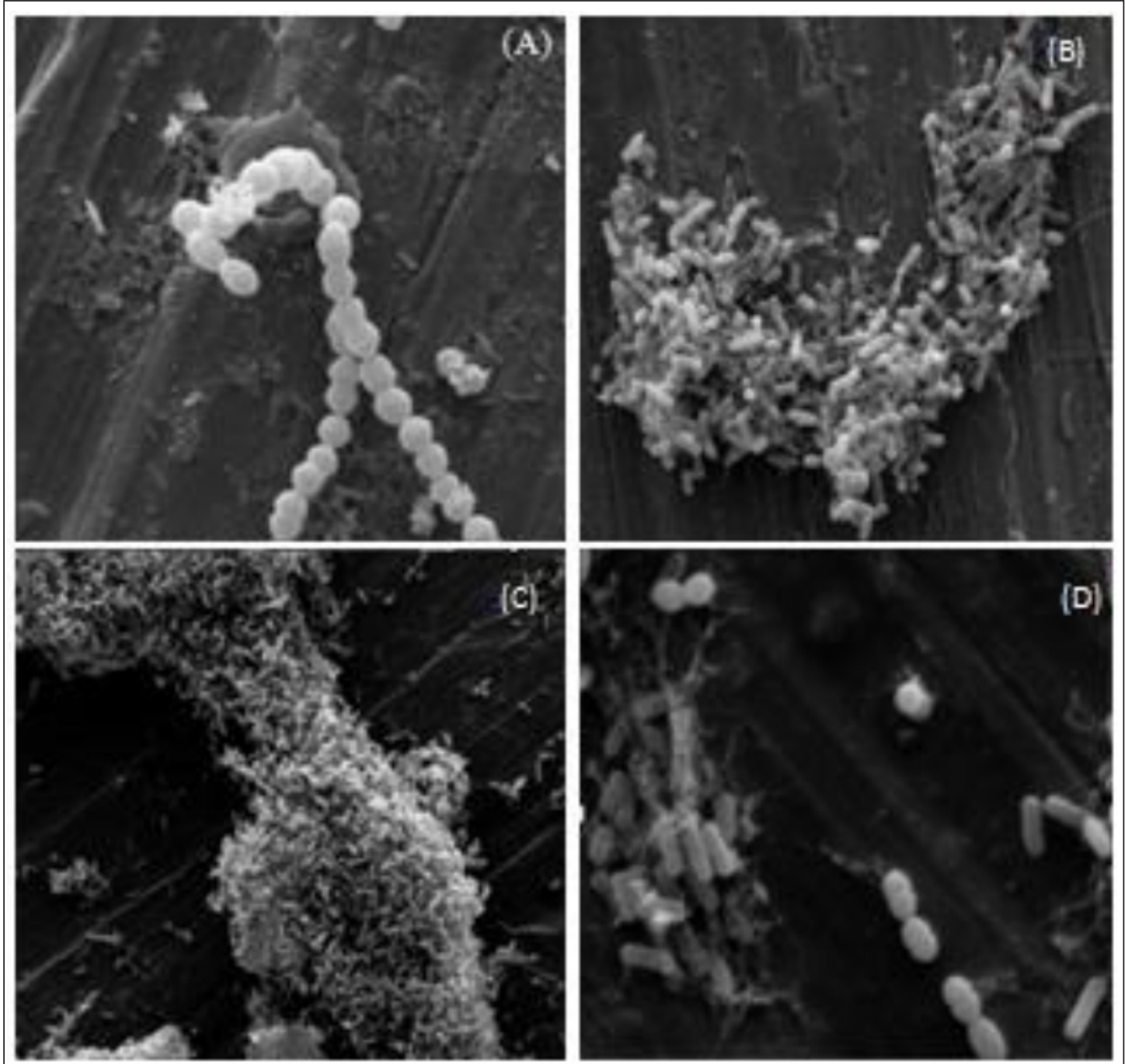

Figure 3 - Electron microscopy of the biofilms formed by Staphylococcus aureus (A), Salmonella spp. (B), Escherichia coli (C) and multispecies (D) on stainless steel surface after $24 \mathrm{~h}$ of incubation at $25^{\circ} \mathrm{C}$.

After $24 \mathrm{~h}$ of adhesion, cells were observed on the surface of the stainless steel coup ons (Figure 3). Possible EPSs, which are important for biofilm adhesion and development, were also observed. Other benefits of EPS include increased access to nutrients, protection against toxins and antibiotics, preservation of the activity of extracellular enzymes, and protection from damage (DANG \& LOVELL, 2000). At T48 and $25^{\circ} \mathrm{C}$, biofilm formation and the presence of EPS were also observed.

After sanitizing the stainless steel coupons that contained preformed biofilms, none of the evaluated strains developed. This result reinforces the importance of following correct procedures for the hygiene of surfaces and respecting cleaning protocols with routine sanitizing because improper sanitation practices foster the development of biofilms, which may be resistant to standard hygiene procedures after forming denser and mature structure.

\section{CONCLUSION}

This study demonstrated that E. coli, $S$. aureus, and Salmonella spp. isolated from raw fish and a fish processing unit have the ability to form biofilms both under single- and multispecies conditions and are potential sources of contamination. However, after appropriate sanitizing, the biofilms were removed, indicating the need for food handling establishments to adopt good manufacturing practices, develop adequate protocols for cleaning and disinfecting 
surface areas and equipment used in food production, maintaining and replacing equipment when necessary.

\section{ACKNOWLEDGEMENTS}

The authors thank the Coordenação de Aperfeiçoamento de Pessoal de Nível Superior (CAPES) for the financial support, to the electron microscope sector of the Institute of Microbiology Prof. Paulo de Góes of the Universidade Federal do Rio de Janeiro (UFRJ) and the Centro Nacional de Biologia Estrutural e Bioimagem (CENABIO) for performing the scanning electron microscopy.

\section{REFERENCES}

ALMEIDA, C. et al. Discriminating multi-species populations in biofilms with peptide nucleic acid fluorescence in situ hybridization (PNA FISH). PLOS One, v.6, n.3, p.1-12, 2011. Available from: $<$ http://journals.plos.org/plosone/article/file?id=10.1371/journal. pone.0014786\&type=printable $>$. Accessed: Aug. 10, 2016. doi: journal. pone. 0014786 .

DANG, H.; C.R. Bacterial primary colonization and early succession on surfaces in marine waters as determined by amplified rRNA gene restriction analysis and sequence analysis of 16S rRNA genes. Applied and Environmnetal Microbiology, v.66, n.2, p.467-475, 2000. Avalaible from: <https://www.ncbi.nlm.nih.gov/pmc/articles/ PMC91850/>. Accessed: June. 30, 2016. doi: 10.1128/AEM.66.2.467475.2000 .

ESPER, L.M.R. Enterobacter sakazakii, Cronobacter spp.e Bacillus cereus: Quorum Sensing, Formação de biofilme e ação de sanitizante. 2010. 103f. Tese (Doutorado em Tecnologia de Alimentos - Curso de Pós-graduação em Tecnologia de Alimentos, Universidade Estadual de Campinas, SP.
GHALY, A.E. et al. Fish spoilage mechanisms and preservation techniques: review. American Journal of Applied Sciences, v.7, n.7, p.859-877, 2010. Avalaible from: <http://thescipub.com/PDF/ ajassp.2010.859.877.pdf $>$. Accessed: June. 30, 2016. doi: 10.3844/ ajassp.2010.859.877.

IWAMOTO, M. et al. Epidemiology of seafood-associated infections in the United Sates. Clinical Microbiology Reviews, v.23, n.2, p.399411, 2010. Avalaible from: $<$ http://cmr.asm.org/content/23/2/399.full. pdf + html> . Accessed: Nov. 22, 2016. doi: 10.1128/CMR.00059-09.

MENON, K.V. Biofilm and food industry. International Journal of Advanced Research in Biological Sciences, v.3, n.4, p.137-142, 2016. Avalaible from: <http://www.ijarbs.com/pdfcopy/apr2016/ijarbs19. pdf $>$. Accessed: Ago. 02, 2016. doi: 1.15/ijarbs-2016-3-4-19.

MINISTÉRIO DA PESCAEAQUICULTURA. Boletim estatístico da pesca e aqüicultura. Brasília, 2011. 60p. (BoletimTécnico, 3).

POMPERMAYER, D.M.; GAYLARD, C.C. The influence of temperature on the adhesion of mixed cultures of Staphylococcus aureus and Escherichia coli to polypropylene. Food Microbiology, v.17, n.4, p.361-365, 2000. Avalaible from: $<$ http://www.sciencedirect. com/science/article/pii/S0740002099902915>. Accessed: Ago. 10, 2016. doi: 10.1006/fmic.1999.0291.

SILVEIRA, M. Preparo de amostras biológicas para microscopia eletrônica de varredura. In: SOUZA, W. Técnicas básicas de microscopia eletrônica aplicadas às ciências biológicas. Rio de Janeiro: Sociedade Brasileira de Microscopia Eletrônica, 1998. Cap.1, p 33-44.

SIMÕES, M. et al. Effect of mechanical stress on biofilms challenged by different chemicals. Water Research, v.39, n.20, p.5142-5152, 2005. Avalaible from: $<\mathrm{http}: / / w w w . s c i e n c e d i r e c t . c o m /$ science/article/ pii/S0043135405005452>. Accessed: July. 07, 2016. doi: 10.1016/j. watres.2005.09.028. 